\title{
STATUS KEBERLANJUTAN KAWASAN PESISIR BERBASIS BUDIDAYA UDANG VANAME DI KECAMATAN INDRAMAYU
}

\author{
Dwi Putri Wigiani $^{\mathrm{a} *}$, Bambang Widigdo ${ }^{\mathrm{a}}$, Kadarwan Soewardi ${ }^{\mathrm{a},}$, Taryono ${ }^{\mathrm{a}}$ \\ ${ }^{a}$ Program Studi Pengelolaan Sumberdaya Pesisir dan Lautan, Sekolah Pascasarjana Institut Pertanian Bogor, \\ Kampus IPB Dramaga, Bogor 16680, Indonesia \\ *Koresponden penulis :dputriwigiani@gmail.com
}

\begin{abstract}
Abstrak
Kecamatan Indramayu merupakan salah satu kecamatan di pesisir Kabupaten Indramayu yang memiliki potensi besar dalam memberikan kontribusi produksi udang vaname melalui kegiatan budidaya baik dengan teknologi tradisional maupun intensif. Budidaya udang di Indramayu yang telah berlangsung sejak tahun 1980-an tentunya memberikan dampak terhadap keberlanjutan kawasan pesisir di sekitarnya. Penelitian ini bertujuan untuk menilai status keberlanjutan kawasan pesisir berbasis kegiatan budidaya udang vaname di Kecamatan Indramayu. Metode yang digunakan adalah metode analisis Rap - Shrimp Farm (Rap-SF) hasil modifikasi dari RAPFISH dengan menggunakan 5 dimensi yaitu ekologi, ekonomi, sosial, hukum dan kelembagaan, serta teknologi. Hasil penelitian menunjukkan bahwa status keberlanjutan kawasan pesisir di Kecamatan Indramayu berdasarkan tingkat teknologinya menunjukkan perbedaan. Indeks keberlanjutan kawasan pesisir berbasis budidaya udang vaname dengan teknologi tradisional plus dikategorikan kurang berkelanjutan dengan nilai indeks yang dihasilkan sebesar 50,36 dan untuk teknologi intensif dikategorikan cukup berkelanjutan dengan indeks keberlanjutan sebesar 51,85. Guna meningkatkan status keberlanjutannya maka direkomendasikan strategi pengelolaan kawasan pesisir berbasis budidaya udang vaname dilakukan dengan pendekatan pengelolaan kawasan budidaya berbasis klasterisasi.
\end{abstract}

Kata kunci: Budidaya udang vaname, Indramayu, keberlanjutan, pesisir

\begin{abstract}
Indramayu Subdistrict is one of the sub-districts on the coast of Indramayu Regency which has great potency to contribute in vaname shrimp production through traditional and intensive aquaculture activities. Shrimp farming have been done in Indramayu since the 1980s and its definitely give some impacts on the sustainability on the coastal areas. This study aims to assess the sustainability status of the coastal area based on vaname shrimp culture in Indramayu District. The assessment done by using a modified RapShrimp Farm (Rap-SF) analysis method, that focused on 5 dimensions which are ecology, economy, social, legal and institutional, and technology. The sustainability index of coastal areas for vaname shrimp culture activities using traditional plus technology are categorized as unsustainable with the index value of 50.36 and for vaname shrimp culture activities using intensive technology are categorized moderate sustainable with a sustainability index of 51.85. According to the index, vaname shrimp culture activities based on clustering management approaches would be a strategy to recommend in order to improve the sustainability of the coastal area in Indramayu.
\end{abstract}

Keywords: Coastal, Indramayu, sustainability, Vaname shrimp culture

\section{PENDAHULUAN}

Kabupaten Indramayu merupakan salah satu kabupaten di Jawa Barat dengan potensi perikanan budidaya yang besar. Secara geografis, Kabupaten Indramayu berada di wilayah pesisir dengan panjang pantai 114 $\mathrm{Km}$ yang berbatasan dengan Laut Jawa sehingga sangat sesuai jika dimanfaatkan untuk pengembangan budidaya air payau khususnya usaha budidaya udang vaname.
Adapun potensi tersebut tergambar dari kemampuan Kabupaten Indramayu berkontribusi terhadap produksi udang vaname di Provinsi Jawa Barat mencapai lebih dari $50 \%$ dari seluruh produksi di Jawa Barat [1].

Kegiatan budidaya udang di tambak sebenarnya sudah lama dilakukan di pesisir Kabupaten Indramayu, khususnya di Kecamatan Indramayu sejak tahun 1980-an. 
Komoditas awal yang dibudidayakan pada saat itu adalah udang windu dan sempat mengalami kejayaan sekitar tahun 1990-an, namun kemudian terjadi penurunan jumlah produksi karena dampak dari kegiatan budidaya udang yang secara masif tanpa memperhitungkan daya dukung lingkungan serta keberlanjutannya.

Budidaya udang kemudian bangkit kembali di awal tahun 2012 dengan komoditas udang vaname dan terjadi perubahan sistem teknologi dari budidaya udang vaname tradisional plus menjadi intensif guna meningkatkan produktivitas udang vaname. Menurut [2] budidaya udang dengan teknologi intensif merupakan kegiatan ekonomi yang sangat produktif dalam meningkatkan kesejahteraan masyarakat dan devisa negara, namun legitimasi keberlanjutannya ditentukan oleh dampak terhadap lingkungan di sekitarnya.

Pemanfaatan wilayah pesisir yang digunakan untuk kegiatan budidaya udang vaname baik dengan teknologi tradisional plus maupun dengan teknologi intensif di Kabupaten Indramayu yang ada saat ini dan upaya pengembangannya ke depan akan menimbulkan dampak terhadap lingkungan sekitarnya jika tidak dilakukan pengelolaan secara bertanggung jawab, sehingga pada akhirnya akan mengancam keberlanjutan sumber daya perikanan yang ada. Terlebih sebagian besar masyarakat di pesisir Kec. Indramayu menjadikan kegiatan budidaya udang vaname sebagai mata pencaharian utama secara turun temurun selain sebagai nelayan. Mengingat arti pentingnya kawasan pesisir bagi masyarakat, maka pembangunan wilayah pesisir harus memenuhi kriteria pembangunan berkelanjutan (sustainable development). Pembangunan berkelanjutan adalah pembangunan yang dapat memenuhi kebutuhan saat ini tanpa mengorbankan kemampuan generasi mendatang untuk memenuhi kebutuhan mereka [3].

Salah satu alternatif pendekatan sederhana yang digunakan untuk menilai keberlanjutan dari sebuah sistem perikanan adalah Rapfish (Rapid Appraissal for Fisheries. Teknik analisis ini dikembangkan untuk mengevaluasi sustainability secara multidisipliner yaitu dengan menyertakan parameter atau atribut ekologi, ekonomi, sosial, etika dan lain -lain [4]. Penelitian ini bertujuan mengukur dan menganalisis status keberlanjutan kawasan pesisir berbasis budidaya udang vaname berdasarkan penerapan tingkat teknologinya yaitu tradisional plus dan intensif di Kecamatan Indramayu serta memberikan rekomendasi pengelolaannya. Merujuk pada konsep pembangunan perikanan berkelanjutan, maka dalam rangka menilai kondisi wilayah pesisir Kecamatan Indramayu yang telah dimanfaatkan oleh kegiatan budidaya udang vaname, perlu kiranya dilakukan pengukuran keberlanjutan dengan mengintegrasikan seluruh dimensi baik aspek ekologi, sosial, ekonomi, hukum dan kelembagaan serta teknologi agar diperoleh gambaran status keberlanjutan dari wilayah pesisir tersebut secara komprehensif.

\section{MATERI DAN METODE PENELITIAN}

Penelitian ini dilaksanakan pada bulan Mei - Agustus 2018. Lokasi penelitian berada di Kecamatan Indramayu, Kabupaten Indramayu.

\section{Pengambilan Data}

Data yang dikumpulkan dalam penelitian ini terdiri atas 5 kategori data yaitu data ekologi, data sosial, data ekonomi, data hukum dan kelembagaan serta data teknologi. Jenis data yang dikumpulkan berupa data primer dan data sekunder baik yang berupa data kuantitatif maupun data kualitatif. Pengumpulan data primer dilakukan dengan menggunakan metode observasi dan pengukuran langsung di lapangan, serta wawancara terstruktur dengan bantuan kuesioner. Pengumpulan data sekunder dilakukan melalui studi pustaka dengan cara mengumpulkan seluruh informasi yang berkaitan dengan kajian/tujuan penelitian, baik yang berasal dari studi pustaka maupun dari informasi berbagai instansi - instansi terkait.

\section{Analisa Data}

Analisis utama yang digunakan adalah analisis keberlanjutan menggunakan metode 
Multi-Dimensional Scalling (MDS). Dalam metode ini, dilakukan proses ordinasi menggunakan teknik ordinasi yang dalam penelitian ini disebut Rapid Appraisal for Shrimp Farm (Rap-SF) yang merupakan modifikasi dari Rap-FISH [5]; [6]. Analisis data dilakukan dengan kompilasi data primer dan sekunder, kemudian data diidentifikasi dalam lima dimensi yaitu ekologi, ekonomi, sosial, hukum dan kelembagaan serta teknologi.

Tahapan analisis mencakup: penentuan atribut; dalam penelitian ini digunakan 31 atribut pada 5 dimensi yang dianalisis, yaitu 5 atribut dimensi ekologi, 9 atribut dimensi ekonomi, 5 atribut dimensi sosial, 5 atribut dimensi hukum dan kelembagaan serta 7 atribut dimensi teknologi; (2) penilaian setiap atribut dalam skala ordinal (scoring) berdasarkan kriteria keberlanjutan pada setiap dimensi; (3) analisis ordinasi Rap-SF dengan menggunakan metode MDS untuk menentukan ordinasi dan nilai stress, (4) penilaian indeks dan status keberlanjutan kawasan pesisir baik pada setiap dimensi maupun secara mutidimensi dengan mengacu pada kriteria keberlanjutan menurut [7]; (5) analisis sensitifitas (leverage analysis) untuk menentukan atribut yang sensitif mempengaruhi keberlanjutan; (6) analisis Monte Carlo untuk mengetahui kestabilan hasil ordinasi dan (7) menyusun strategi pengelolaan.

Tabel 1. Indeks keberlanjutan kawasan pesisir berbasis budidaya udang vaname

\begin{tabular}{ll}
\hline Nilai Indeks & Kategori \\
\hline$\leq 25$ & Buruk/tidak berlanjut \\
$26-50$ & Kurang berkelanjutan \\
$51-75$ & Cukup berkelanjutan \\
$\geq 76$ & Baik/sangat berkelanjutan \\
\hline
\end{tabular}

Estimasi dengan teknik MDS menghasilkan nilai S Stress untuk mengetahui goodness of fit dari model yang dibangun. Model yang baik memiliki nilai S Stress yang lebih kecil dari 0,25 [8]. Faktor dominan/sensitif terhadap keberlanjutan dikarakterisasi berdasar hasil analisis leverage yang sudah diintegrasikan di dalam MDS.
Penentuan faktor dominan/sensitif terhadap keberlanjutan dilakukan berdasarkan pada nilai Root Mean Square (RMS) terbesar, semakin besar perubahan RMS karena hilangnya atribut tertentu, berarti atribut semakin sensitif perannya bagi keberlanjutan. Pada tahap selanjutnya, dilakukan analisis Monte Carlo untuk menduga pengaruh kesalahan (galat) pada tingkat kepercayaan 95\% atau dengan kata lain, memperhitungkan ketidakpastian (uncertainty).

\section{HASIL DAN PEMBAHASAN}

Hasil analisis menggunakan Rap Shrimp Farm (Rap-SF) disajikan dalam bentuk kite - diagram (Gambar 1). Analisis multidimensi terhadap keberlanjutan kawasan pesisir berbasis budidaya udang vaname dengan teknologi tradisional plus menunjukkan bahwa dimensi teknologi, dimensi ekonomi dan dimensi hukum \& kelembagaan merupakan dimensi yang tergolong kurang berkelanjutan, sedangkan dimensi ekologi dan sosial tergolong cukup berkelanjutan. Indeks multidimensi keberlanjutan kawasan pesisir berbasis budidaya udang vaname dengan teknologi tradisional plus di Kecamatan Indramayu adalah 50,36 atau kurang berkelanjutan. Indeks keberlanjutan dapat ditingkatkan melalui intervensi pada atribut yang sensitif.

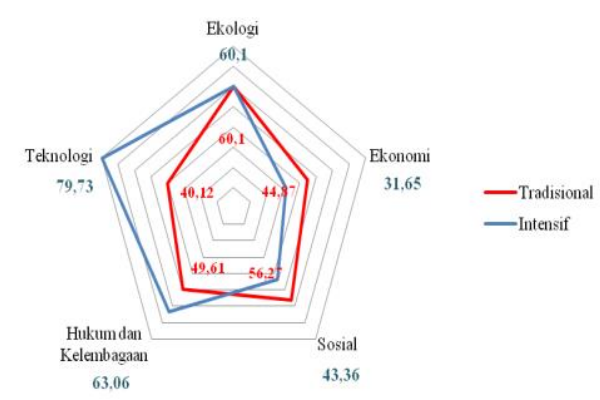

Gambar 1. Diagram layang keberlanjutan

Indeks keberlanjutan kawasan pesisir berbasis budidaya udang vaname dengan teknologi intensif memperlihatkan bahwa dimensi ekologi, dimensi hukum dan kelembagaan serta dimensi teknologi 
tergolong cukup berkelanjutan dan dimensi ekonomi dan sosial tergolong kurang berkelanjutan. Indeks multidimensi keberlanjutan kawasan pesisir berbasis budidaya udang vaname dengan teknologi intensif di Kecamatan Indramayu adalah 51,85 atau cukup berkelanjutan.

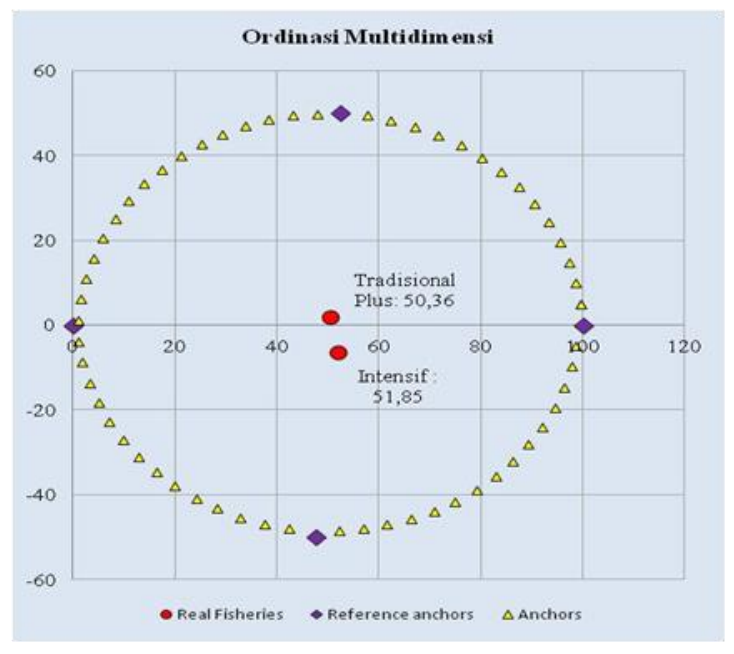

Gambar 2. Indeks keberlanjutan multidimensi

Gambar 1 memperlihatkan bahwa indeks keberlanjutan untuk setiap dimensi berbeda - beda. Dalam sebuah konsep pembangunan berkelanjutan bukan berarti semua indeks dari setiap dimensi harus memiliki nilai yang sama besar, namun dalam berbagai kondisi di daerah penelitian tentu memiliki prioritas terhadap dimensi yang lebih dominan untuk menjadi perhatian. Atribut yang teridentifikasi sensitif akan dijadikan sebagai acuan atau prioritas dalam merumuskan strategi pengelolaannya berbasis pada dinamika yang terjadi di lingkungan setempat [9]. Misalnya jika dilihat dari dimensi ekologi, penyusunan peraturan daerah terkait upaya pengelolaan kawasan pesisir yang akan dikembangkan sebagai kawasan budidaya udang vaname di Kabupaten Indramayu dipandang perlu untuk dilaksanakan dengan mengacu pada hasil kajian daya dukung kawasan (carrying capacity).

\section{Status Keberlanjutan Dimensi Ekologi}

Hasil analisis MDS menunjukkan bahwa nilai indeks keberlanjutan dimensi ekologi adalah 60,10 kategori cukup berkelanjutan. Hasil penelitian ini sejalan dengan [10] yang menyebutkan bahwa penilaian terhadap dimensi ekologi sistem budidaya udang vaname dengan teknologi super intensif dan intensif di Jawa Barat termasuk dalam kategori cukup berkelanjutan. Dimensi ekologi merupakan dimensi utama dalam menjaga keseimbangan sumber daya alam dan lingkungan agar dapat dikelola secara berkelanjutan untuk generasi yang akan datang [11].

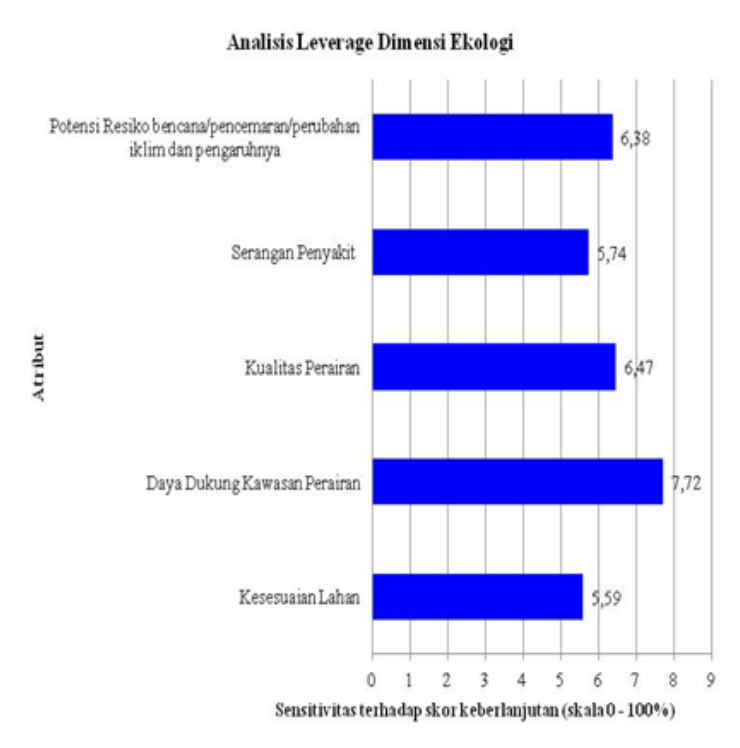

Gambar 3. Hasil analisis Leverage dimensi ekologi

Analisis Leverage menunjukkan bahwa 3 dari 5 atribut memberikan pengaruh yang nyata terhadap tingkat keberlanjutan ekologi, yaitu: daya dukung kawasan; kualitas perairan dan potensi risiko bencana/pencemaran/perubahan iklim dan pengaruhnya. Hasil analisis leverage disajikan pada Gambar 3.

Konsep pengelolaan sumber daya alam dan lingkungan secara berkelanjutan dikembangkan untuk mencegah kerusakan atau degradasi sumber daya alam dan lingkungan. Hasil perhitungan daya dukung kawasan pesisir berdasarkan pada perhitungan Total Suspended Solids (TSS) memperlihatkan bahwa kawasan pesisir Kec. Indramayu masih berada pada kondisi yang masih dapat menerima buangan hasil limbah hasil kegiatan budidaya udang vaname. TSS digunakan sebagai dasar pengukuran daya 
dukung dikarenakan TSS dianggap sebagai indikator yang dapat merepresentasikan pencemaran fisik yang terjadi di perairan. Menurut [12] Ammonium dan padatan tersuspensi yang dikeluarkan tambak merupakan limbah yang sangat berpengaruh terhadap perairan pesisir. Pembuangan sejumlah besar nutrisi dengan konsentrasi tinggi dan padatan tersuspensi secara potensial mempunyai dampak kurang baik terhadap air penerima, termasuk merangsang blooming algae dan meningkatnya kondisi anoxic [13].

Tahapan awal untuk mengukur daya dukung perairan dalam menampung beban tersebut perlu diketahui terlebih dahulu volume perairan pesisir Kec. Indramayu dengan mengacu pada rumus [14]. Pada saat ini volume perairan Kec. Indramayu berjumlah 11.957.333,33 liter. Sedangkan jumlah TSS yang yang dihasilkan dari kegiatan budidaya udang vaname di Kec. Indramayu dari luas tambak sekitar $701,71 \mathrm{Ha}$ adalah 5.493.385,57 liter, maka dapat diketahui bahwa perairan pesisir Kec. Indramayu masih dapat menampung beban limbah TSS sebesar 6.463.947,76 liter.

Status keberlanjutan dimensi ekologi dapat dipertahankan atau bahkan ditingkatkan apabila budidaya udang vaname dilakukan di lahan yang telah ditetapkan melalui hasil kajian baik kualitas lingkungan perairan dan lahan maupun penanganan dampak limbah yang dihasilkan dari kegiatan tersebut. Secara hukum, lahan yang dimaksud seharusnya telah memiliki landasan hukum seperti tertuang dalam Rencana Tata Ruang dan Wilayah (RTRW) maupun Rencana Zonasi Wilayah Pesisir dan Pulau - pulau Kecil (RZWP3K). Untuk itu, pemerintah daerah selaku pemangku kebijakan sudah semestinya mengimplementasikan hasil kajian yang terkait dengan daya dukung lahan (carrying capacity) dalam menentukan arah pembangunan perikanan budidaya khususnya budidaya udang vaname di Kec. Indramayu.

\section{Status Keberlanjutan Dimensi Ekonomi}

Hasil analisis MDS menunjukkan bahwa indeks keberlanjutan kawasan pesisir berbasis budidaya udang vaname dengan teknologi tradisional plus sebesar 44,86 dan untuk teknologi intensif sebesar 31,65. Berdasarkan klasifikasi kondisi tersebut menurut [7], maka dimensi ekonomi termasuk dalam kategori kurang berkelanjutan untuk sembilan atribut yang dikaji. Analisis leverage menunjukkan, bahwa terdapat empat atribut yang berpengaruh terhadap keberlanjutan kawasan pesisir yaitu permodalan, alternatif mata pencaharian selain budidaya, rata-rata pendapatan relatif terhadap UMR dan harga. Secara rinci hasil indeks keberlanjutan dan analisis leverage disajikan pada Gambar 4.

Atribut permodalan menjadi atribut penting dalam keberlanjutan kawasan pesisir berbasis budidaya udang vaname. Dari hasil penelitian diketahui bahwa rata - rata pembudidaya tradisional plus menggunakan modal yang berasal dari dana sendiri maupun dengan cara menggantungkan usahanya pada keberadaan pedagang pengumpul atau yang biasa disebut bakul. Ketergantungan tersebut terwujud dalam suatu keterikatan hutang dimana pembudidaya diberikan modal berupa benih dan pakan dengan syarat harus mengembalikan hutang dan menyetorkan hasil panennya kepada pengumpul yang memberi modal [15].

Berbeda dengan pembudidaya tradisional plus, pembudidaya intensif memperoleh modal berasal dari lembaga pembiayaan atau perbankan dikarenakan budidaya tambak intensif merupakan kegiatan yang sarat modal atau dalam kata lain membutuhkan modal dalam jumlah yang besar. Permodalan menjadi hal yang sangat menentukan dalam keberlanjutan secara usaha maupun keberlanjutan kawasan pesisir/lingkungan di sekitarnya dilihat dari dampak yang ditimbulkannya.

Menurut Fauzi [16] konsep keberlanjutan ini paling tidak mengandung dua dimensi: pertama adalah dimensi waktu karena keberlanjutan tidak lain menyangkut apa yang akan terjadi di masa mendatang. Kedua adalah dimensi interaksi antara sistem ekonomi dan sistem sumber daya alam dan lingkungan. Peningkatan status keberlanjutan dari dimensi ekonomi dalam penelitian ini memerlukan upaya preventif dari lembaga pembiayaan dalam memberikan kredit modal 
yang berwawasan lingkungan dengan memasukkan klausul pencegahan pencemaran lingkungan hidup/penilaian kelestarian lingkungan dalam persyaratan pemberian modal usaha budidaya [17].

Perlunya dokumen Analisa Dampak Lingkungan (AMDAL) sebagai salah satu persyaratan perizinan usaha bagi pembudidaya udang vaname dengan teknologi intensif menjadi salah satu upaya menjaga kelestarian lingkungan sebagaimana telah diamanatkan dalam Peraturan Menteri Kelautan dan Perikanan (Permen KP) Nomor 49 Tahun 2014 tentang Usaha Pembudidayaan Ikan.

Sejalan dengan hal tersebut, perbankan/lembaga pembiayaan sesuai dengan amanat Undang - Undang Perbankan Nomor 10 Tahun 1998 dalam Pasal 8 ayat (1) telah menempatkan lingkungan hidup sebagai salah satu pertimbangan dalam pemberian kredit seperti disebutkan bahwa bank dalam memberikan kredit atau pembiayaan berdasarkan prinsip syariah harus memperhatikan hasil Analisis Dampak Lingkungan (AMDAL) bagi debitur yang berskala besar dan/atau berisiko tinggi agar proyek yang dibiayai tetap menjaga kelestarian lingkungan. Hal tersebut menggambarkan adanya sinkronisasi regulasi antara pemerintah (pusat maupun daerah) sebagai instansi yang menerbitkan izin dan AMDAL dengan lembaga pembiayaan, bank maupun non bank yang bertujuan menjaga kelestarian lingkungan.

\section{Status Keberlanjutan Dimensi Sosial}

Hasil analisis MDS menunjukkan bahwa indeks keberlanjutan kawasan pesisir berbasis budidaya udang vaname dengan teknologi tradisional plus sebesar 56,26 termasuk dalam kategori cukup berkelanjutan dan kurang berkelanjutan untuk teknologi intensif sebesar 43,35. Analisis leverage menunjukkan bahwa terdapat dua atribut yang berpengaruh terhadap keberlanjutan kawasan pesisir yaitu sosialisasi pekerjaan dan frekuensi konflik. Secara rinci hasil analisis leverage disajikan pada Gambar 5.

Dimensi sosial memiliki keterkaitan yang erat terhadap keberlanjutan ekosistem kawasan pesisir Kecamatan Indramayu. Masyarakat memiliki kehidupan sosial yang beragam karena berasal dari berbagai suku dan latar belakang yang berbeda. Kemajemukan tersebut menyebabkan terjadi berbagai interaksi sosial dalam pemanfaatan kawasan pesisir untuk keberlanjutan hidup masyarakat.

Berdasarkan hasil penelitian disampaikan bahwa mayoritas pembudidaya tradisional plus melakukan kegiatan tersebut dengan bekerja sama dengan keluarga sementara pembudidaya intensif melakukan kegiatan budidaya secara individu. Keberadaan kegiatan akuakultur pada suatu kawasan diupayakan tidak menimbulkan terjadinya konflik sosial. Penataan kawasan budidaya sesuai dengan RTRW dan atau zonasi serta upaya mengurangi kesenjangan sosial diharapkan dapat meminimalisir timbulnya konflik eksternal. Konflik internal (antar pembudidaya) dapat diminimalisir dengan meningkatkan peran kelembagaan sosial dan atau peningkatan komunikasi sosial. Penerimaan sosial merupakan bagian yang terintegrasi dari keberlanjutan. Merupakan suatu masalah yang biasa terjadi pada saat kegiatan budidaya telah berkembang beberapa komponen masyarakat menunjukkan ketidakpuasan melalui konflik [18].

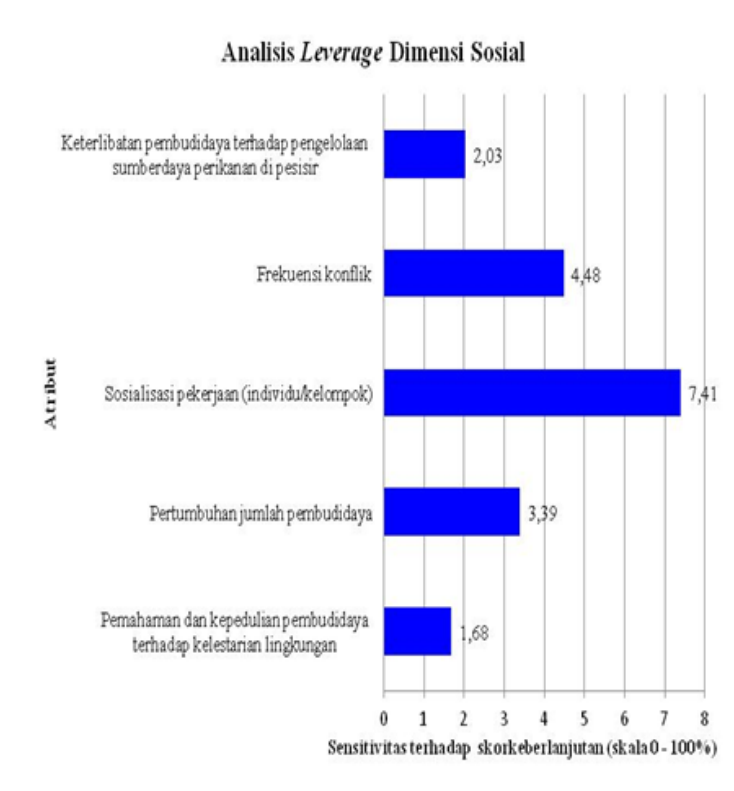

Gambar 5. Hasil analisis Leverage dimensi sosial 


\section{Keberlanjutan Dimensi Hukum dan Kelembagaan}

Hasil analisis MDS menunjukkan bahwa indeks keberlanjutan kawasan pesisir berbasis budidaya udang vaname dengan teknologi tradisional plus sebesar 49,61 termasuk dalam kategori kurang berkelanjutan dan cukup berkelanjutan untuk teknologi intensif sebesar 63,06. Analisis leverage menunjukkan bahwa terdapat tiga atribut yang berpengaruh terhadap keberlanjutan kawasan pesisir yaitu ketersediaan peraturan tentang budidaya udang atau aturan perijinan, ketersediaan dokumen zonasi dan konsistensi tataguna lahan dengan RTRW dan penegakan hukum terkait dengan kegiatan budidaya udang vaname di kawasan pesisir. Secara rinci hasil analisis leverage disajikan pada Gambar 6.

Berdasarkan hasil penelitian, adapun konflik yang sering kali berpotensi terjadi adalah berkaitan dengan pemanfaatan sumber air. Menurunnya fungsi sarana dan prasarana yang mendukung kegiatan budidaya udang vaname seperti saluran irigasi yang mengalirkan air tawar guna kebutuhan tambak banyak yang mengalami pendangkalan dan rusaknya tanggul di sepanjang saluran tersebut sering kali menyebabkan terjadinya perebutan sumber air tawar. Pembuangan limbah hasil budidaya/pada saat panen juga dapat mendorong terjadinya konflik karena saluran pembuangan merupakan saluran yang digunakan bersama dalam satu kawasan budidaya udang vaname di Kecamatan Indramayu. Namun sampai dengan saat ini belum pernah terjadi konflik yang besar, masih dapat diatasi dengan musyawarah kekeluargaan. Keberadaan peraturan terkait tata cara pemanfaatan sumber daya dalam suatu wilayah merupakan hal penting dalam rangka menghindari konflik kepentingan.

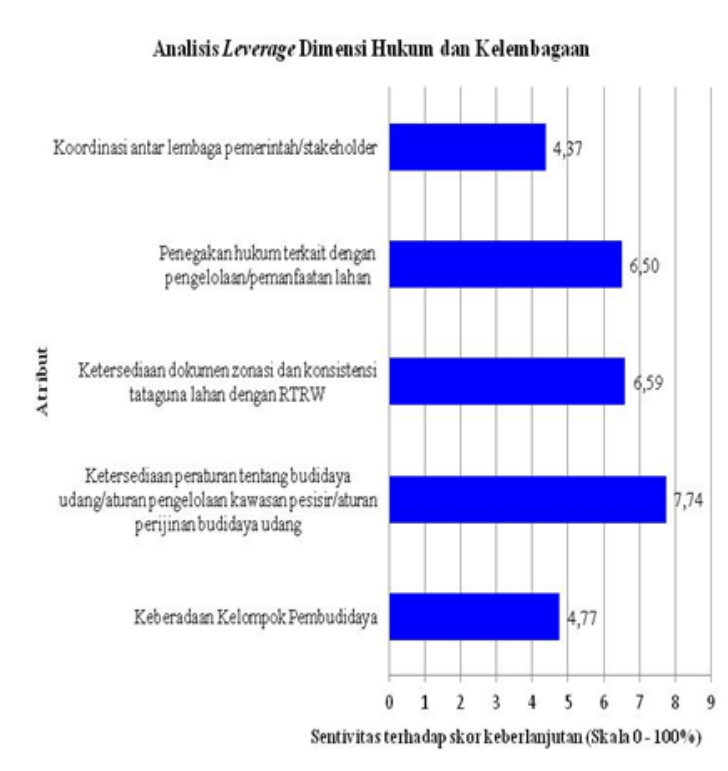

Gambar 6. Hasil analisis Leverage dimensi hukum \& kelembagaan

Sampai dengan saat ini di Kabupaten Indramayu, telah tersedia beberapa peraturan yang terkait dengan pengaturan pemanfaatan lahan maupun petunjuk teknis budidaya udang vaname dan syarat administrasinya. Peraturan tersebut antara lain Peraturan Daerah (Perda) Provinsi Jawa Barat No. 16 Tahun 2013 tentang RZWP3K Provinsi Jawa Barat Tahun 2013 - 2029, Perda No 1 Tahun 2012 tentang RTRW Kabupaten Indramayu 2011 - 2031, peraturan mengenai petunjuk teknis Cara Budidaya Ikan yang Baik (CBIB) Kepmen No. KEP.02/MEN/2007 tentang CBIB, Standar Nasional Indonesia (SNI) udang vaname yang dimulai dari proses pembenihan, produksi dan pakan buatannya, Permen KP Nomor 49 tahun 2014 tentang Usaha Pembudidayaan Ikan maupun Permen KP Nomor 75 tahun 2016 tentang pembesaran udang windu dan udang vaname.

Berdasarkan hasil penelitian, di Kecamatan Indramayu didapatkan fakta bahwa mayoritas pembudidaya kurang mengetahui tersedianya aturan - aturan tersebut secara utuh dan jelas. Untuk itu, guna meningkatkan status keberlanjutan kawasan pesisir yang diukur dari dimensi hukum dan kelembagaan maka diperlukan langkah penguatan kelembagaan. Keberlanjutan kawasan pesisir akan dipengaruhi oleh ada 
tidaknya peran suatu kelembagaan yang berwenang mengatur para pemilik kepentingan dalam memanfaatkan kawasan pesisir yang sama dengan kawasan budidaya.

\section{Keberlanjutan Dimensi Teknologi}

Hasil analisis MDS menunjukkan bahwa indeks keberlanjutan kawasan pesisir berbasis budidaya udang vaname dengan teknologi tradisional plus sebesar 40,12 termasuk dalam kategori kurang berkelanjutan dan sangat berkelanjutan untuk teknologi intensif sebesar 79,73. Analisis leverage menunjukkan bahwa terdapat tiga atribut yang berpengaruh terhadap keberlanjutan kawasan pesisir yaitu penggunaan pakan, pengelolaan air limbah dan penggunaan benih. Secara rinci hasil indeks keberlanjutan dan analisis leverage disajikan pada Gambar 7.

Keberlanjutan dari dimensi teknologi pada prinsipnya dipengaruhi oleh beberapa hal yang berada pada tingkatan mikro atau on farm. Salah satu atribut yang sensitif adalah penggunaan pakan. Berdasarkan hasil penelitian diketahui bahwa pembudidaya tradisional plus mayoritas melakukan pemberian pakan berdasarkan feeling perkiraan dari pengalaman sehari - hari sedangkan pembudidaya intensif melakukan pemberian pakan berdasarkan perhitungan dari hasil sampling yang dilakukan secara rutin. Kuantitas dan kualitas pakan merupakan hal penting untuk diperhatikan. Komposisi pakan harus seminimal mungkin yang menyebabkan penyuburan perairan. Jumlah dan kualitas pakan yang cukup dan cara pemberiannya yang baik dan benar dapat mendukung keberlanjutan proses budidaya dan sekaligus memperkecil dampak negatif dari sisa pakan yang terbuang ke lingkungan di kawasan pesisir.

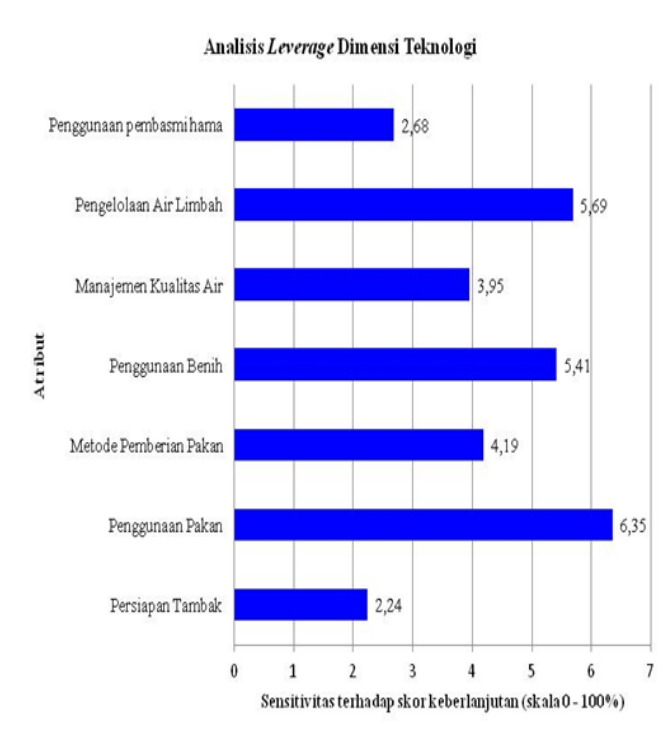

Gambar 7. Hasil analisis Leverage dimensi teknologi

Atribut selanjutnya yang berpengaruh terhadap keberlanjutan dari dimensi teknologi adalah pengelolaan air limbah. Berdasarkan hasil penelitian, pembudidaya tradisional plus mayoritas tidak melakukan pengelolaan air limbah (effluent), sedangkan bagi pembudidaya intensif rata - rata telah memiliki tandon sebagai instalasi pengolahan air limbah buangan. Dampak yang ditimbulkan jika limbah buangan (effluent) tambak dikeluarkan tanpa perlakuan adalah mengandung konsentrasi nitrogen yang tinggi dan dapat berakibat pada turunnya kualitas air laut atau saluran yang dilaluinya. Tingginya konsentrasi nitrogen di perairan juga dapat mengakibatkan defisit oksigen karena dekomposisi bahan organik dan eutrofikasi karena akumulasi nitrogen dan fosfor [19]. Kondisi kualitas air buangan di kawasan budidaya seharusnya sudah memenuhi kriteria baku mutu lingkungan.

Berdasarkan hal tersebut di atas, maka untuk menjaga keberlanjutan ekosistem dalam suatu kawasan budidaya harus dilakukan dengan menjalankan proses budidaya berkelanjutan. Kepatuhan praktik budidaya sesuai dengan standar CBIB dan atau sertifikasi lainnya yang telah ada menjadi kunci keberlanjutan kawasan/ekosistem pesisir berbasis budidaya udang vaname. 


\section{Parameter Statistik}

Hasil analisis Monte Carlo pada taraf kepercayaan $95 \%$ menunjukkan adanya selisih perhitungan yang relatif kecil pada nilai MDS yang dihasilkan analisis Rap- Shrimp Farm dengan uji Monte Carlo. Selisih yang kecil ini memperlihatkan bahwa kesalahan dalam analisis terhadap skoring setiap atribut relatif kecil, variasi pemberian skoring karena perbedaan opini juga kecil, proses analisis cukup akurat dan kesalahan in put data serta data hilang dapat dihindari. Selisih perbedaan nilai MDS dengan uji Monte Carlo berkisar antara 0,01 - 3,04. Hal ini membuktikan tingkat akurasi hasil analisis Rap - Shrimp Farm cukup tinggi.

Pada tahap selanjutnya, dilakukan pengujian terhadap nilai Stress dan koefisien determinasi dari atribut - atribut yang dianalisis guna mengetahui sesuai/tidak sesuai dengan kaidah ilmiah. Hasil analisis untuk nilai stress dan koefisien determinasi $\left(\mathrm{R}^{2}\right)$ disajikan pada tabel 2. Nilai stress dan koefisien determinasi menunjukkan bahwa hasil analisis cukup akurat dan dapat dipertanggungjawabkan secara ilmiah. Hal ini dibuktikan dengan nilai stress lebih kecil dari 0,25 dan koefisien determinasi mendekati nilai 1,0 [20].

Tabel 2. Hasil analisis Rap-SF untuk beberapa parameter statistik

\begin{tabular}{lrrrrrrr}
\multirow{2}{*}{ Parameter } & \multicolumn{7}{c}{ Dimensi Keberlanjutan } \\
\cline { 2 - 8 } & A & B & C & D & E & F \\
\hline $\begin{array}{l}\text { Stress } \\
\text { R²(Koefisien }\end{array}$ & 0,16 & 0,14 & 0,18 & 0,16 & 0,14 & 0,13 \\
Determinasi) & 0,94 & 0,92 & 0,93 & 0,92 & 0,94 & 0,95 \\
Iterasi & 2 & 2 & 2 & 2 & 3 & 2 \\
\hline Ket: & $\begin{array}{l}\text { A:Ekologi; } \\
\text { D:Hukum\&Kelembagaan }\end{array}$ & B: & Ekonomi; & C: & \multicolumn{2}{c}{ Sosial; } \\
& $\begin{array}{l}\text { Teknologi; } \\
\text { F:Multidimensi }\end{array}$ & & & &
\end{tabular}

Hasil analisis Monte Carlo membuktikan bahwa tidak semua dimensi mendukung keberlanjutan kawasan pesisir berbasis budidaya udang vaname di Kec. Indramayu secara signifikan. Tiga dimensi utama yang mendukung keberlanjutan kawasan pesisir adalah dimensi ekologi, hukum \& kelembagaan dan teknologi. Akurasi dukungan dimensi - dimensi tersebut terhadap keberlanjutan kawasan pesisir dibuktikan dengan nilai stress dan koefisien determinasi yang diperoleh (Tabel 2).

Kondisi lapangan juga mendukung hal tersebut mengingat hasil perhitungan daya dukung perairan dalam dimensi ekologi masih memungkinkan untuk dilakukannya pengembangan kawasan budidaya udang vaname dengan menerapkan prinsip cara budidaya ikan yang baik serta dilakukan di kawasan/lahan yang telah ditetapkan peruntukannya sebagai kawasan budidaya dalam RTRW Kab. Indramayu.

Upaya meningkatkan status keberlanjutan kawasan pesisir dapat tercapai apabila pengelolaan kawasan tambak yang berada di pesisir Kecamatan Indramayu melibatkan peran dari seluruh stakeholders yang memiliki kepentingan di sana. Untuk itu diperlukan tindakan kolektif dalam pengelolaan kawasan pesisir berbasis budidaya udang vaname agar keberlanjutan kawasan pesisir di sekitarnya maupun usaha budidaya udang vaname dapat ditingkatkan statusnya menjadi cukup berlanjut atau bahkan sangat berlanjut. Salah satu bentuk pengelolaan kolektif tersebut adalah dengan sistem klaster [18]. Klaster budidaya memiliki pengertian sebagai gabungan, kumpulan atau kelompok objek yang memiliki fungsi sebagai pendukung proses budidaya baik secara langsung maupun tidak langsung. Fokus dari penerapan klaster budidaya adalah penerapan tata kelola sarana dan prasarana utama maupun penunjang sehingga mampu meningkatkan produktivitas lahan budidaya yang dilakukan dengan pengembangan sistem tata kelola ruang yang efesien dan menguntungkan serta berwawasan lingkungan [21].

Secara teknis di lapangan idealnya sistem klaster tersebut nantinya dapat dikelompokkan berdasarkan lahan tambak sesuai dengan tingkatan teknologinya yaitu tambak tradisional dan tambak intensif. Adanya klaster budidaya udang vaname di Kecamatan Indramayu nantinya dapat menjadi salah satu upaya dalam mempersempit area kontrol dan meningkatkan kesadaran masyarakat terhadap lingkungan dengan menerapkan budidaya yang ramah lingkungan dan berkelanjutan. 


\section{KESIMPULAN}

Kesimpulan yang diperoleh dari hasil penelitian ini yaitu: Indeks multidimensi keberlanjutan kawasan pesisir berbasis budidaya udang vaname dengan teknologi tradisional plus di Kecamatan Indramayu adalah 50,36 atau kurang berkelanjutan dan dengan teknologi intensif adalah 51,85 atau cukup berkelanjutan dengan didukung oleh dimensi ekologi, hukum dan kelembagaan serta teknologi. Strategi pengelolaan kawasan pesisir berbasis budidaya udang vaname guna meningkatkan status keberlanjutannya di Kec. Indramayu yaitu dengan pendekatan klasterisasi lahan budidaya berdasarkan tingkat teknologinya.

\section{DAFTAR PUSTAKA}

[1] Direktorat Jenderal Perikanan Budidaya (DJPB) Kementerian Kelautan dan Perikanan. Statistik Perikanan Budidaya Tahun 2017. Jakarta.

[2] T. Supraptono, D. Puspito, Siswanto, Poniran, dan Suyoto, Optimalisasi produktivitas tambak idle melalui budidaya multispesies dengan sistem pemeliharaan paralel dan resirkulasi. Laporan Kegiatan Balai Besar Pengembangan Budidaya Air Payau Jepara. hal.209- 219, 2008.

[3] WCED (World Commission on Enviroment and Development) (ed). Our Common Future. Oxford (US). Oxford University Pr. 1987.

[4] A. Fauzi dan S. Anna. Pemodelan sumberdaya perikanan dan kelautan untuk analisis kebijakan. Gramedia Pustaka Utama. Jakarta. 2005.

[5] P. Kavanagh. RAPFISH software description (for microsoft excel). Rapid appraisal of fisheries (Rapfish) project (36p). Vancouver. University of British Columbia. Fisheries Centre. 2001.
[6] T.J. Pitcher, and D.B. Preikshot, "Rapfish: A rapid appraisal technique to evaluate the sustainability status of fisheries," Fisheries Research 49(3), hal 255-270, 2001.

[7] S.B. Susilo. Keberlanjutan pembangunan pulau-pulau kecil: studi kasus kelurahan pulau panggang dan pulau pari, Kepulauan Seribu, DKI Jakarta. [disertasi]. Bogor. Institut Pertanian Bogor. 2003.

[8] A.S. Hasrat, J. Haluan, dan I.K Budiastra, "Status keberlanjutan pengelolaan perikanan budidaya di pulau - pulau kecil Makassar," $J$. Manajemen Perikanan dan Kelautan, Vol 1 No 1, 2014.

[9] J. Alder, T.J. Pitcher, D. Preikshot, K. Kaschner, and B. Feriss, "How good is good? A Rapid appraisal technique for evaluation of the sustainability status of fisheries of the North Atlantic. In Pauly and Pitcher (eds). Methods for evaluationg the impacts of fisheries on the north Atlantic ecosystem", Fisheries Center Research Reports 8(2), hal. 136 - 182, 2000.

[10] W. Hadie dan L.E. Hadie, "Analisis sistem budidaya untuk mendukung kebijakan keberlanjutan produksi udang," J. Kebijakan Perikanan Indonesia. 9(1), hal 51-60, 2017.

[11] M. Djamhur. Model Pengembangan Kawasan Konservasi Pesisir dan PulauPulau Kecil Berbasis Zonasi (Kasus di Teluk Weda) [disertasi]. Bogor. Institut Pertanian Bogor. 2014.

[12] A. Tovar, C. Moreno, M.P. Maâ NuelVez and M. G. A-Vargas, "Environmental impacts of intensive aquaculture in marine waters", $J$. Water Research, vol 34 no. 1, hal 334 342, Januari, 2000. http:/DOI: 10.1016/S0043-1354(99)00102-5. 
[13] M. A. Burforda, P.J. Thompsona, R.P. McIntoshb, R.H. Baumanb, and D.C. Pearsonc, "The contribution of flocculated material to shrimp (Litopenaeus vannamei) nutrition in a high-intensity, zero-exchange system", J. Aquaculture, vol 232 (1-4), hal 525537, April, 2004. http:/ DOI: 10.1016/S0044-8486(03)00541-6

[14] Widigdo B. dan J Pariwono, "Daya dukung perairan di Pantai Utara Jawa Barat untuk budidaya udang (Studi kasus di Kabupaten Subang, Teluk Jakarta dan Serang)", Jurnal Ilmu-ilmu Perairan dan Perikanan Indonesia, Vol 10(1), hal 10-17, 2003.

[15] E. Suryanegara dan Hikmah, "Hubungan patron-klien pada usaha budidaya udang windu (Penaeus monodon) dan bandeng (Chanos chanos) di Kabupaten Indramayu, Jawa Barat", Buletin Riset Sosek Kelautan dan Perikanan, Vol. 7 no. 2, 2012.

[16] A. Fauzi. Ekonomi sumber daya alam dan lingkungan (teori dan aplikasi). Gramedia Pustaka Utama.Jakarta.2004.

[17] M.I. Ansari, "Implikasi pengaturan lingkungan hidup terhadap peraturan perundang - undangan dalam kegiatan bisnis (Perspektif Konstitusi)", Jurnal Konstitusi volume 11, Nomor 2, Juni 2014.

[18] A.Y. Montolure. Pengelolaan kawasan pesisir dengan pendekatan ekologi untuk optimasi tambak tradisional (studi kasus Kecamatan Bokat, Kabupaten Buol). [tesis]. Bogor Institut Pertanian. Bogor. 2016.

[19] B. Romadhona, B.Yulianto dan Sudarno," Fluktuasi kandungan amonia dan beban cemaran lingkungan tambak udang vaname intensif dengan teknik panen parsial dan panen total", Jurnal Saintek Perikanan, Vol.11 no.2, hal 8493, Februari 2016.
[20] P. Kavanagh $P$ and T.J. Pitcher. Implementing Microsoft Excel software for Rapfish: a technique for the rapid appraisal of fisheries status. Fisheries Centre Research Reports, University of British Columbia, Canada. 12(2). pp 75. 2004.

[21] Direktorat Jenderal Perikanan Budidaya (DJPB) Kementerian Kelautan dan Perikanan. Petunjuk teknis klaster pembesaran udang vaname di tambak. Jakarta. 2017. 